\title{
Comparison of fruit maturation and quality of 'Gala' apple strains at harvest and after storage
}

\author{
Luiz Carlos Argenta ${ }^{1}$, Cassandro Vidal Talamini do Amarante ${ }^{2}$, Thyana Lays Brancher ${ }^{3}$, \\ Karyne Souza Betinelli ${ }^{4}$, Vinícius Adão Bartinick ${ }^{5}$, Cristiano Nunes Nesi ${ }^{6}$
}

\begin{abstract}
Strains of 'Gala' apples with highly red-colored skins have been planted in new orchards based on consumer interest and financial returns to the producers. The effect of somatic mutation may not be limited to change in fruit skin appearance. In this study, six 'Gala' strains were compared regarding fruit maturity and quality attributes at commercial harvest time and after 210 days in controlled atmosphere cold storage plus seven days shelf-life. Experimental orchards were established in three regions and fruit assessed over four seasons. The fruit skin red color area was highest in 'Baigent' and 'Galaxy', and lowest in 'Royal Gala' and 'Imperial Gala'. Fruit of 'Maxi Gala' and 'Gala Real' had intermediate skin coloration among the six strains. There was no difference among the strains regarding the fruit weight, starch index, flesh firmness, soluble solid content (SSC), and titratable acidity (TA) at harvest, and flesh firmness, SSC and TA after storage. Fruit of the six 'Gala' strains were equally affected by physiological disorders (flesh browning, fruit cracking, calcium deficiency disorders and shrivel) and fungal diseases (external decay, core rot and Glomerella cingulata spot) during storage, indicating that they have similar storability. Only 'Imperial Gala' and 'Royal Gala' exhibited superficial scald, an unusual disorder for 'Gala' cultivar. Harvest management and potential economic impacts of highly red colored fruit of 'Gala' strains are discussed.
\end{abstract}

Index Terms: Malus $\times$ domestica Borkh., fruit skin color, storability, physiological disorder, disease.

\section{Comparação da maturação e qualidade de maçãs de clones mutantes de 'Gala' na colheita e após a armazenagem}

Corresponding author:
argenta@epagri.sc.gov.br

Received:july 22, 2020

Accepted: October 29, 2020

Copyright: All the contents of this journal, except where otherwise noted, is licensed under a Creative Commons Attribution License.

(cc) EY

\begin{abstract}
Resumo - Mutantes de maçãs cv. Gala com maior coloração vermelha na epiderme têm sido plantados em novos pomares devido ao interesse dos consumidores e ao retorno financeiro aos produtores. $\mathrm{O}$ efeito de mutações somáticas, das quais os novos mutantes de maçãs têm sido originados, pode não se limitar à mudança da aparência da epiderme. Neste estudo, frutos de seis clones mutantes de 'Gala' foram comparados quanto a medidas de maturação e qualidade no período de colheita comercial e após a armazenagem sob atmosfera controlada refrigerada. Pomares experimentais foram estabelecidos em três regiões, e os frutos, analisados ao longo de quatro anos. A área da epiderme com coloração vermelha foi máxima nos frutos da 'Baigent' e 'Galaxy' e mínima nos frutos da 'Royal Gala' e 'Imperial Gala'. Frutos da 'Maxi Gala' e 'Gala Real' apresentaram coloração avermelhada intermediária entre os seis mutantes. Não houve diferença significativa entre frutos dos seis clones mutantes quanto à massa, índice de amido, firmeza da polpa, conteúdo de sólidos solúveis (CSS) e acidez titulável (AT) na colheita e quanto à firmeza de polpa, CSS e AT após a armazenagem. Os frutos dos seis clones foram igualmente afetados por distúrbios fisiológicos (escurecimento da polpa, rachadura senescente, distúrbios por deficiência de cálcio e murcha) e por doenças (podridão externa, podridão carpelar e pintas de Glomerella cingulata) durante a armazenagem, indicando que eles têm o mesmo potencial de armazenagem. Apenas frutos da 'Imperial Gala' e 'Royal Gala' desenvolveram sintomas de escaldadura superficial, um distúrbio raro na cultivar Gala. O manejo da colheita e os potenciais impactos econômicos de mutantes de 'Gala' com alta coloração vermelha são discutidos.
\end{abstract}

Termos para indexação: Malus $\times$ domestica Borkh., cor da epiderme do fruto, armazenagem, distúrbio fisiológico, doença.

\footnotetext{
Agronomist. D.Sc., Researcher at Epagri, Experimental Station of Caçador, Caçador-SC. Brazil. Email: argenta@epagri.sc.gov.br (oRcıd: 00000001-9614-0523)

${ }^{2}$ Agronomist, PhD., Professor at the Agronomy Department, Universidade Estadual de Santa Catarina/Lages-SC. Brazil. Email: cassandro. amarante@udesc.br (ORCID: 0000-0003-0563-2093)

${ }^{3}$ Industrial biotechnologist, Doctoral student at Universidade Federal de Lavras, Lavras-MG. Brazil. Email: thyanalays@hotmail.com ${ }^{\text {(ORcID: }}$ 0000-0003-3337-6314)

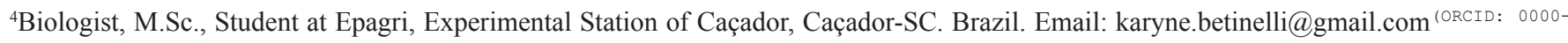
$0001-7242-0002)$

${ }^{5}$ Agronomist. Dr. at Proterra Engenharia Agronômica Ltda, Estrada Federal BR 116, nº 7320, Vacaria, RS. Brazil. Email: viniciusbartnicki@ gmail.com (ORCID 0000-0003-3204-8968)

${ }^{6}$ Agronomist. D.Sc., Researcher at Epagri, Experimental Station of Chapecó, Chapecó-SC. Brazil. Email: cristiano@epagri.sc.gov.br ${ }^{\circ \mathrm{ORC} \text { D }}$
} 


\section{Introduction}

'Gala' is the major apple cultivar currently grown in Brazil, accounting for about $60 \%$ of the total production (PÉRÈS, 2009). The original 'Gala' fruit ('Kidd's D.8') has a cream-yellow skin with an orange-red cheek when grown in warm summer weather conditions (GREENE;AUTIO, 1993). Apple production of this cultivar increased throughout the world after mid-1970's when strains with improved red coloration in fruit skin appeared as spontaneous bud mutations in commercial orchards (HAMPSON; KEMP, 2003).

Skin color is an important trait of apple fruit quality that influences attractiveness to consumers and the profitability of apple production. Hence, several new strains of 'Gala' apples with highly red-colored skins have been selected and propagated in new orchards of main apple production regions along the last decades. Fruit appearance is sensorially evaluated by consumers and influences initial purchase decision (JAEGER et al., 2018). Increasing preference for apple strains with redder skin coloration based on the sensory assessment of visual appearance has been demonstrated in bicolor or red cultivars (CRASSWELLER; HOLLENDER, 1989; KAPPEL et al., 1992; GREENE; AUTIO, 1993; HAMADZIRIPI et al., 2014). Besides, apples deviating from expected color or with external defects are perceived by consumers to be less tasty (DE HOOGE et al., 2017; JAEGER et al., 2018). Apple fruit price is influenced mainly by cultivar, quality grade, marketing season and fruit size (CAREW, 2000; CAREW; SMITH, 2004; ARGENTA et al., 2015). Currently, grade standards (classification system of quality) for apples, established by the industry and government regulations (e.g. MAPA, 2006; OECD, 2010) are based on fruit appearance. On red and bicolored apples, the extent of red skin coloration, as well as the incidence and severity of defects are the major measures of appearance (external quality). Apple fruit with suboptimal appearance leads to a decrease in consumers' willingness to purchase (YUE et al., 2007; JAEGER et al., 2018) and are marketed at a lower price which reduces producer profitability (CAREW; SMITH, 2004).

Fruit of many 'Gala' strains selected for enhanced red coloration have similar maturity profile, size and sensory taste at harvest (KAPPEL et al., 1992; RAPILLARD and DESSIMOZ, 2000; IGLESIAS et al., 2008; IGLESIAS; ECHEVERRÍA, 2009). However, some have earlier or later maturation, larger or smaller size, higher or less sugar content and firmer texture than the fruit of the parent tree (WALSH; VOLZ, 1990; GREENE; AUTIO, 1993; BROWN; MALONEY, 2002; MALLADI; HIRST, 2010; FINN; CLARK, 2012; BROWN; MALONEY, 2013). Besides, apple strains selected for highly red-colored skin may be differently scored for taste (CRASSWELLER; HOLLENDER, 1989; GREENE; AUTIO, 1993; IGLESIAS et al., 2012).
While fruit quality and maturation have been characterized for many 'Gala' apple strains at harvest time, information about the storability of different apple fruit strains is scarce. This study was carried out to compare the fruit physicochemical and quality attributes of six 'Gala' apple strains grown in southern Brazil, at harvest and after storage.

\section{Material and Methods}

\section{Experimental orchard blocks and design}

Fruit of the six 'Gala' strains (treatments) were compared in six experimental orchards (the combination of the three locations and two rootstocks). The experimental orchards were established at EPAGRI Caçador, EPAGRI São Joaquim, and EMBRAPA Vacaria (three locations), in southern Brazil, in 2007. In each location, two sets of rows were established with the following 'Gala' apple strains: 'Royal Gala', 'Imperial Gala', 'Gala Real', 'Maxi Gala', 'Galaxy', and 'Baigent'. In one set of rows, the six 'Gala' strains were on rootstock M.9 at $1.0 \times 3.5 \mathrm{~m}$ spacing. In another set of rows, the six 'Gala' strains were on rootstock 'Marubakaido' with M.9 interstem at 1.4 x 4 $\mathrm{m}$ spacing. 'Fuji' trees were planted as pollinizers within each row of 'Gala' trees. In each experimental orchard, the experiment followed a complete randomized block design (three blocks) with 10 trees per replicate. The apple trees were trained to a central leader. Standard orchard practices (soil fertilization, dormancy release of buds, pruning, crop thinning and pest and disease control) were followed according to each local guidelines (EPAGRI, 2018).

\section{Fruit harvest, sampling and storage}

Fruit were harvested over four growing seasons (from $5^{\text {th }}$ to $8^{\text {th }}$ year after planting) within the commercial harvest window. The harvest date was predicted by previous starch index analyses. Fruit of all 'Gala' strains (treatments) were harvested on the same day in each year and location. Apple fruit grown in São Joaquim reaches similar maturity to those grown in Caçador region seven days later (ARGENTA et al., 1995). Therefore, for this study, fruit from São Joaquim were picked seven and five days later than in Caçador and Vacaria, respectively.

A sample of 100 unblemished fruits was selected from each replicate: 25 apples per replicate were assessed for maturity and quality one day after harvest, and 75 apples per replicate were assessed for quality after storage. Fruit intended for storage were packed in fiberboard trays and cartons boxes $(18 \mathrm{~kg})$ and cooled within $36 \mathrm{~h}$ of harvest. Fruit were stored in controlled atmosphere (CA) room (with $1.5 \mathrm{kPa} \mathrm{O}_{2}$ and $2.5 \mathrm{kPa} \mathrm{CO}_{2}$, at $0.8 \pm 0.6{ }^{\circ} \mathrm{C}$ and relative humidity of approximately $92 \%$ ) for 210 days, and then held in regular air, at $22{ }^{\circ} \mathrm{C}$, for seven days shelf life. Establishment of CA conditions was initiated 
$4 \mathrm{~h}$ after fruit cooling to $0.8{ }^{\circ} \mathrm{C}$ and final atmosphere was established $48 \mathrm{~h}$ after cooling.

\section{Fruit assessment}

Maturity and quality attributes were assessed for each fruit except for fresh weight, soluble solids content (SSC) and titratable acidity (TA). Fruit weight was determined for four samples of 25 fruit per replicate, while SSC and TA were determined for three fresh juice samples using longitudinal slices of fruit cheeks taken from eight fruits per replicate. Assessments of flesh firmness, starch index (1-9 scale), TA and SSC were performed as previously described (ARGENTA et al., 2020).

The percentage area of red-colored skin was determined subjectively by the ratio of reddish surface area to overall fruit surface area. Mottled areas or traces of light-green or yellowish-white background between red stripes were not counted as red-colored areas.

External and internal disorders were visually assessed using subjective scales of severity, where a score of 0 (zero) indicated the absence of disorders. Internal disorders were assessed from four transverse slices across the fruit. The severity of disorders was recorded according to the area of fruit surface or cortex cross-section affected or the number of lesions per fruit.

Fruit with russeting was rated as $1,1-4 \%$ of surface affected, confined to stem cavity; $2,5-10 \% ; 3,11-25 \%$; or $4,>25 \%$. Fruit with superficial scald was rated as 1 , 2 , or 3 , when symptoms were observed on $\leq 15 \%, 16$ $40 \%$, or $>40 \%$ of the fruit surface, respectively. Bitter pit was scored considering the number of brown pits on the skin and or corky lesions in the cortex, per fruit: 1, 1-4 pits; 2, 5-9 pits; or 3, $>9$ pits. These scores were also used for the assessment of lenticel breakdown and Glomerella cingulata spot. Dry brown spots around lenticels characterized lenticel breakdown; this disorder was restricted to the skin without extending to the flesh tissue. Fruit cracking (from the shoulder area to over the cheek, in the skin and underlay flesh) and shrivelling were recorded as absent (0) or present (1). Flesh browning was assessed on a single cross section of fruit at equatorial region (at the upper edge of seed cavity). Fruit affected by this disorder was scored as $1,1-30 \%$ of cortex with diffuse light browning; 2, 30-60\% of cortex with diffuse light to dark browning; or 3, $>60 \%$ of cortex with diffuse light to dark browning. Fruit with external fungal decay symptoms were rated as $1, \leq 1 \mathrm{~cm}^{2}$ of fruit surface affected by one or more spots; or 2,>1 $\mathrm{cm}^{2}$ of fruit surface affected. Fruit affected by core rot was rated as $1,<50 \%$ of core tissue rotted; 2,50 to $100 \%$ of core tissue rotted; or 3, damage spread to the cortex tissue.

An index of incidence weighted by severity (disorder index) was calculated for each disorder as previously described (ARGENTA et al., 2020).

\section{Data analysis}

Data for the six experiments (the combination of two rootstocks and three growing locations) and four growing seasons were pooled $(\mathrm{n}=72$ per strain) and initially subjected to non-parametric Kruskal-Wallis test for multiple comparisons of 'Gala' strains (treatments) using R (TEAM-R-CORE, 2017) and the add-on package 'agricolae' (MENDIBURU, 2017).

The data of 'Gala' strains were subjected to canonical discriminant analysis (CDA; a multivariate statistical analysis) using the PROC CANDISC procedure of the SAS software (University Edition 2017, SAS Institute, Cary, NC) for each group of variables: 1) quality and maturity at harvest; 2) physicochemical attributes after storage; 3) physiological disorders; 4) diseases. Values for standardized canonical coefficients (SCC) and canonical correlations $(r)$ were multiplied to calculate the parallel discriminant ratio coefficient (DRC) as proposed by (THOMAS and ZUMBO, 1996). Plots of canonical scores were used to visualize how the first two canonical discriminant functions $\left(\mathrm{CDF}_{1}\right.$ and $\left.\mathrm{CDF}_{2}\right)$ accounted for separation among strains for each group of variables. Mean standardized canonical scores of 'Gala' strains were compared by Tukey's test $(\mathrm{P} \leq 0.05)$ along canonical discriminant functions (CDFs).

\section{Results and Discussion}

The fruit of six 'Gala' strains differed significantly regarding the area of red skin coloration (Table 1). However, there was no difference among the strains regarding the fruit weight, starch index, flesh firmness, soluble solids content (SSC), or titratable acidity (TA) at harvest, and flesh firmness, SSC or TA of the fruit after storage plus shelf life. 
Table 1. Quality and maturity variables of 'Gala' apple fruit of six strains at harvest and after storage. Fruit were stored in controlled atmosphere $\left(1.5 \mathrm{kPa} \mathrm{O}_{2}\right.$ and $\left.2.5 \mathrm{kPa} \mathrm{CO}_{2}\right)$ at $0.8^{\circ} \mathrm{C}$ for seven months, followed by seven days in air at $22^{\circ} \mathrm{C}$. Data are means of three growing locations, two rootstocks and four growing seasons $(\mathrm{n}=72)$.

\begin{tabular}{|c|c|c|c|c|c|c|}
\hline 'Gala' strain & $\begin{array}{l}\text { Red skin color } \\
\text { area }(\%)\end{array}$ & $\begin{array}{l}\text { Weight } \\
(\mathrm{g})\end{array}$ & $\begin{array}{c}\text { Starch index } \\
(1-9)\end{array}$ & $\begin{array}{c}\text { Flesh firmness } \\
(\mathrm{N})\end{array}$ & $\begin{array}{c}\text { Titratable acidity } \\
(\%)\end{array}$ & $\begin{array}{l}\text { Soluble solids } \\
\text { content }(\%)\end{array}$ \\
\hline & \multicolumn{6}{|c|}{ At harvest } \\
\hline 'Baigent' & $74 \mathrm{a}$ & $138^{\text {ns }}$ & 5.8 ns & $16.7^{\text {ns }}$ & 0.364 ns & $13.0^{\mathrm{ns}}$ \\
\hline ‘Galaxy’ & $74 \mathrm{a}$ & 136 & 5.7 & 17.1 & 0.372 & 13.2 \\
\hline 'Maxi Gala' & $70 \mathrm{a}$ & 138 & 5.6 & 16.8 & 0.375 & 13.2 \\
\hline 'Gala Real’' & $62 \mathrm{~b}$ & 135 & 5.5 & 16.9 & 0.369 & 13.0 \\
\hline 'Imperial Gala' & $55 \mathrm{c}$ & 139 & 5.4 & 17.1 & 0.384 & 13.3 \\
\hline \multirow[t]{2}{*}{ 'Royal Gala' } & $54 \mathrm{c}$ & 134 & 5.4 & 17.1 & 0.375 & 13.2 \\
\hline & \multicolumn{6}{|c|}{ After storage } \\
\hline 'Baigent' & - & - & - & $10.5^{\text {ns }}$ & $0.301^{\text {ns }}$ & $13.4^{\mathrm{ns}}$ \\
\hline ‘Galaxy’ & - & - & - & 10.9 & 0.310 & 13.6 \\
\hline 'Maxi Gala' & - & - & - & 10.6 & 0.317 & 13.6 \\
\hline 'Gala Real' & - & - & - & 11.1 & 0.304 & 13.5 \\
\hline 'Imperial Gala' & - & - & - & 11.1 & 0.307 & 13.6 \\
\hline 'Royal Gala' & - & - & - & 11.1 & 0.311 & 13.6 \\
\hline
\end{tabular}

Means followed by different letter in each column are different according to Kruskal-Wallis test $(\alpha=0.05)$. ns: means in each column are not different according to Kruskal-Wallis test $(\alpha=0.05)$.

The Wilk's Lambda multivariate statistical of the CDA showed difference $(\mathrm{P}<0.0001)$ among the six strains, considering all fruit attributes assessed at harvest (Table 2). Only $\mathrm{CDF}_{1}$ was significant, explaining $95.36 \%$ of total variance, with canonical correlation of 0.6391 , indicating strong association between attributes studied and strains. The percentage area of red-colored skin had the highest power to discriminate among strains along
$\mathrm{CDF}_{1}$ (higher DRC), while fruit weight had negative DRC value, representing suppressor attribute (reflecting higher variability within and or low variability among strains). Therefore, the separation among strains along $\mathrm{CDF}_{1}$, regarding attributes assessed at harvest, is explained almost entirely by the red skin color.

Table 2. Correlation coefficients $(r)$, standardized canonical coefficients (SCC) and parallel discriminant ratio coefficients $(\mathrm{DRC})$ for canonical discriminant function $1\left(\mathrm{CDF}_{1}\right)$. Canonical discriminant analysis $(\mathrm{CDA})$ performed considering all variables assessed at harvest. Data of three growing locations, two rootstocks and four growing seasons were pooled $(\mathrm{n}=72)$.

\begin{tabular}{lccc}
\hline \multirow{2}{*}{ Variable } & \multicolumn{3}{c}{$\mathrm{CDF}_{\text {1 }}$} \\
\cline { 2 - 4 } & $r^{(1)}$ & $\mathrm{SCC}$ & $\mathrm{DRC}$ \\
\hline Red skin color area (\%) $\mathbf{( 1 )}^{(\mathbf{1}}$ & $\mathbf{0 . 6 7 6 7}$ & $\mathbf{1 . 3 5 5 7}$ & $\mathbf{0 . 9 1 7 4}$ \\
${\text { Mean fruit weight }(\mathrm{g})^{(1)}}^{\text {Starch index (1-9) }}{ }^{(2)}$ & 0.0086 & -0.4127 & -0.0036 \\
Flesh firmness (N) $^{(2)}$ & 0.1001 & 0.1183 & 0.0118 \\
Titratable acidity (\%) $^{(2)}$ & -0.0909 & -0.0824 & 0.0075 \\
Soluble solids content (\%) $^{(2)}$ & -0.0802 & -0.5603 & 0.0449 \\
Canonical correlation $^{(2)}$ & -0.0701 & -0.3127 & 0.0219 \\
\hline
\end{tabular}

(1) Simple correlation between each variable and $\mathrm{CDF}_{1}$.

(2) Canonical correlations among strains and quality and maturity variables. ***: $\mathrm{P}<0.001$. 
Canonical scores revealed clear discrimination among strains at harvest along $\mathrm{CDF}_{1}$ (Figure 1). Fruit of 'Baigent' and 'Galaxy' had the highest standardized canonical scores (representing fruit with the highest area of red skin coloration), while on the other extreme, 'Royal Gala' and 'Imperial Gala' had the lowest scores (representing fruit with the lowest area of red skin coloration). 'Maxi Gala' and 'Gala Real' had intermediate canonical scores (representing fruit with intermediate red coloration among the strains) although 'Maxi Gala' had higher canonical scores than 'Gala Real'.
When red skin coloration was not included in the CDA for fruit variables assessed at harvest, there was no differences among 'Gala' strains (Figure 2A). Similarly, CDA showed no differences among the 'Gala' strains for flesh firmness, SSC and TA assessed after storage (Figure 2B).

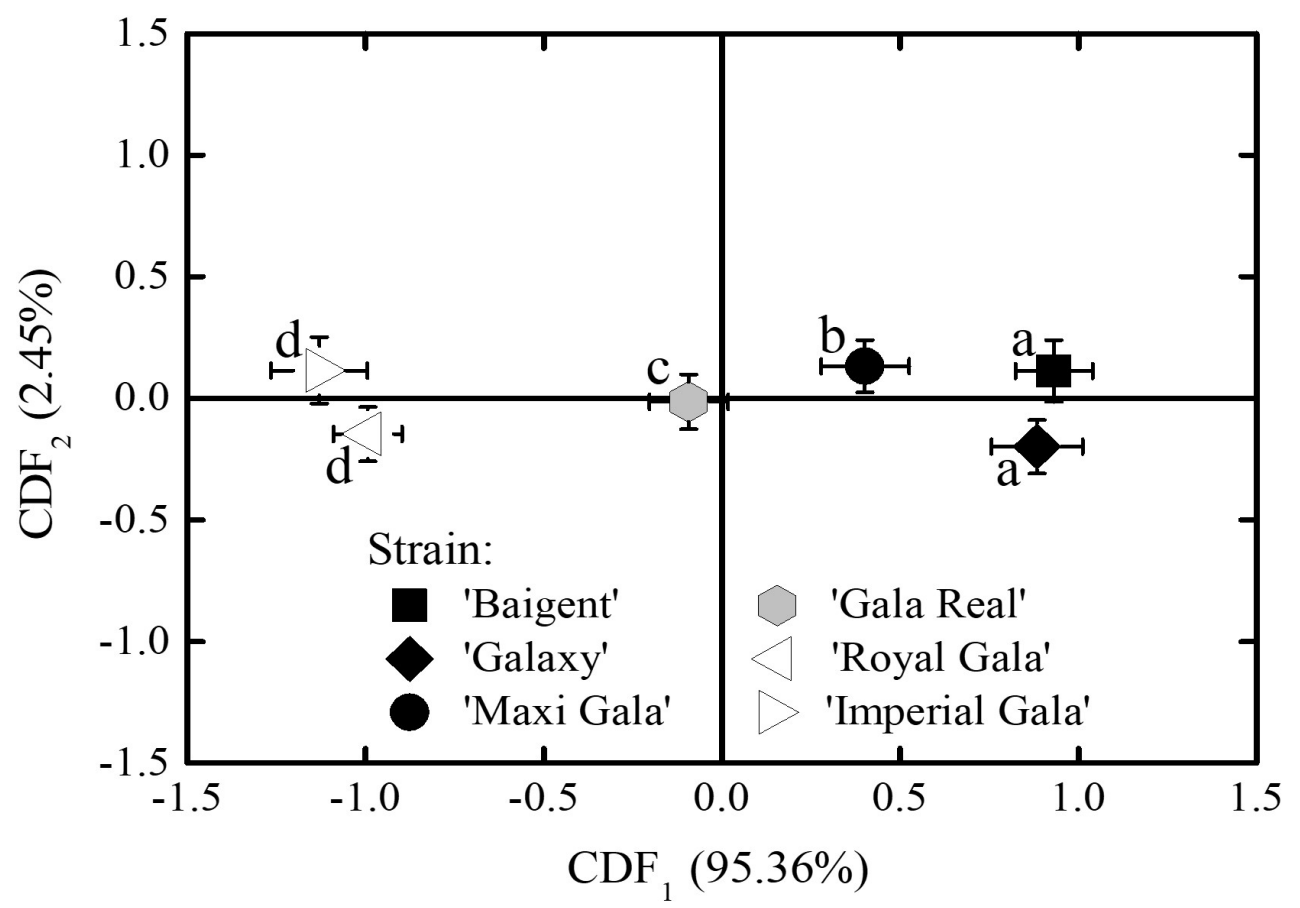

Figure 1. Canonical scores of 'Gala' apples strains considering all maturity and quality variables assessed at harvest described in Table 2. Strains with mean standardized canonical scores ( $\pm \mathrm{SE}$ ) along $\mathrm{CDF}_{1}$ followed by the same letter are not different by Tukey's test $(\mathrm{P} \leq 0.05)$. Values in brackets represent the proportion of total variance explained by $\mathrm{CDF}_{1}$ and $\mathrm{CDF}_{2}$. Data of three growing locations, two rootstocks and four growing seasons were pooled $(\mathrm{n}=72)$.

The univariate non-parametric test showed that the index of russeting - a physiological disorder that develops during fruit growth - was slightly greater on the surface of 'Royal Gala' apples than on 'Baigent' or 'Maxi Gala' apples, while there was no difference among 'Gala' strains regarding the indexes of flesh browning, senescent fruit cracking, bitter pit, shrivel and lenticel breakdown (Table
3). The symptom of superficial scald was detected only on 'Imperial Gala' and 'Royal Gala' fruit, at a very low index. Also, there was no difference among 'Gala' strains regarding the fungal disease indices (external decay, core rot and Glomerella cingulata spot) after storage plus shelf life (Table 4). 

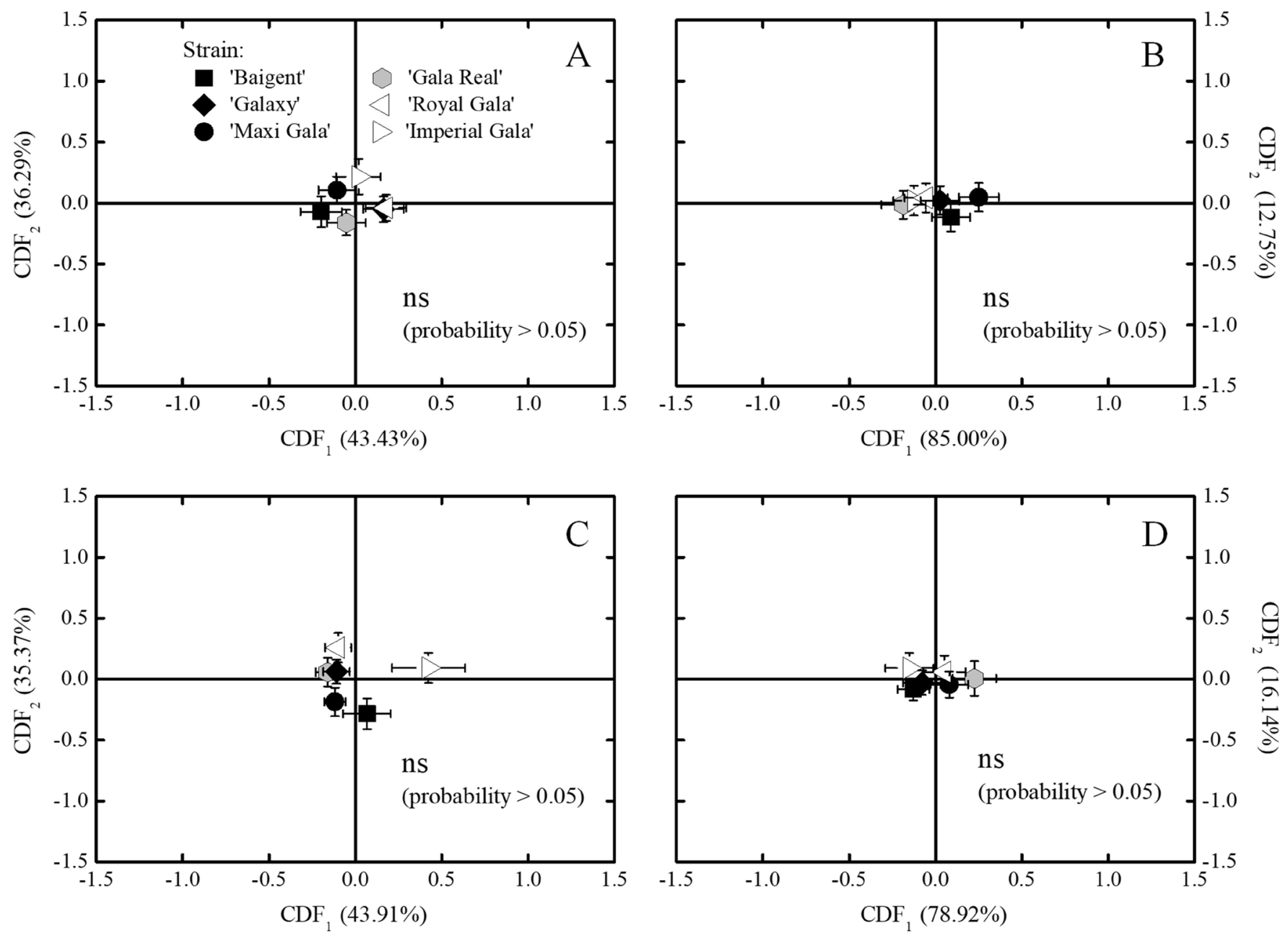

Figure 2. Canonical scores of 'Gala' apples strains considering quality and maturity variables assessed at harvest (variables in Table 2) except for red skin color area (A), physicochemical variables (flesh firmness, TA and SSC) assessed after storage (B), physiological disorders (russeting, flesh browning, skin cracking, bitter pit, shrivel, superficial scald and lenticel breakdown) (C) and diseases (external decay, core rote and Glomerella cingulata spot) (D). Values in brackets represent the proportion of total variance explained by $\mathrm{CDF}_{1}$ and $\mathrm{CDF}_{2}$. ns: canonical scores of strains along $\mathrm{CDF}_{1}$ are not significantly different by Tukey's test $(\mathrm{P}>0.05)$. Symbols represent the mean standardized canonical scores $( \pm \mathrm{SE})$ along $\mathrm{CDF}_{1}$ and $\mathrm{CDF}_{2}$. Data of three growing locations, two rootstocks and four growing seasons were pooled $(\mathrm{n}=72)$.

Table 3. Physiological disorders indices (incidence weighted to the severity) in 'Gala' apple fruit of six strains. Russeting were assessed at harvest while the other disorders were assessed after seven months storage in controlled atmosphere $\left(1.5 \mathrm{kPa} \mathrm{O}_{2}\right.$ and $\left.2.5 \mathrm{kPa} \mathrm{CO}_{2}\right)$ at $0.8{ }^{\circ} \mathrm{C}$, followed by seven days in air at $22{ }^{\circ} \mathrm{C}$. Data are means of three growing locations, two rootstocks and four growing seasons $(\mathrm{n}=72)$.

\begin{tabular}{llcccccc}
\hline 'Gala' strain & Russeting & $\begin{array}{c}\text { Flesh } \\
\text { browning }\end{array}$ & $\begin{array}{c}\text { Fruit } \\
\text { cracking }\end{array}$ & Bitter pit & Shrivel & $\begin{array}{c}\text { Superficial } \\
\text { scald }\end{array}$ & $\begin{array}{c}\text { Lenticel } \\
\text { breakdown }\end{array}$ \\
\hline 'Baigent' & $19.2 \mathrm{~b}$ & $15.3^{\mathrm{ns}}$ & $3.9^{\mathrm{ns}}$ & $0.040^{\mathrm{ns}}$ & $0.038^{\mathrm{ns}}$ & $0.000 \mathrm{~b}$ & $0.046^{\mathrm{ns}}$ \\
'Galaxy' & $21.8 \mathrm{ab}$ & 12.7 & 3.5 & 0.021 & 0.044 & $0.000 \mathrm{~b}$ & 0.022 \\
'Maxi Gala' & $19.7 \mathrm{~b}$ & 13.3 & 3.3 & 0.038 & 0.039 & $0.000 \mathrm{~b}$ & 0.015 \\
'Gala Real' & $21.5 \mathrm{ab}$ & 10.5 & 3.0 & 0.038 & 0.054 & $0.000 \mathrm{~b}$ & 0.015 \\
'Imperial Gala' & $20.7 \mathrm{ab}$ & 12.6 & 3.7 & 0.017 & 0.015 & $0.140 \mathrm{a}$ & 0.056 \\
'Royal Gala' & $24.5 \mathrm{a}$ & 13.1 & 3.6 & 0.015 & 0.019 & $0.007 \mathrm{ab}$ & 0.012 \\
\hline
\end{tabular}

Means followed by different letter in each column are different according to Kruskal-Wallis test $(\alpha=0.05)$. ${ }^{\text {ss: }}$ means in each column are not different according to Kruskal-Wallis test $(\alpha=0.05)$. 
Table 4. Fungal disease indices (incidence weighted to the severity) in 'Gala' apple fruit of six strains. Fruit were assessed after seven months of storage in controlled atmosphere $\left(1.5 \mathrm{kPa} \mathrm{O}_{2}\right.$ and $\left.2.5 \mathrm{kPa} \mathrm{CO}_{2}\right)$ at $0.8^{\circ} \mathrm{C}$, followed by seven days in air at $22^{\circ} \mathrm{C}$. Data are means of three growing locations, two rootstocks and four growing seasons $(\mathrm{n}=72)$.

\begin{tabular}{lccc}
\hline 'Gala' strain & External decay & Core rot & Glomerella cingulata spot \\
\hline 'Brookfield' & $6.5^{\mathrm{ns}}$ & $0.022^{\mathrm{ns}}$ & $0.21^{\mathrm{ns}}$ \\
'Galaxy' & 6.5 & 0.028 & 0.30 \\
'Maxi Gala' & 5.6 & 0.047 & 0.35 \\
'Gala Real' & 4.9 & 0.042 & 0.56 \\
'Imperial Gala' & 7.5 & 0.027 & 0.46 \\
'Royal Gala' & 6.2 & 0.043 & 0.36 \\
\hline
\end{tabular}

Means followed by different letter in each column are different according to Kruskal-Wallis test $(\alpha=0.05)$. ${ }^{\text {ns: }}$ means in each column are not different according to Kruskal-Wallis test $(\alpha=0.05)$.

The Wilk's Lambda multivariate statistical test of the CDA showed no difference $(\mathrm{P}>0.05)$ among the 'Gala' strains regarding physiological disorders (russeting, flesh browning, fruit cracking, bitter pit, shrivel, superficial scald and lenticel breakdown) (Figure 2C) and diseases (external decay, core rot and Glomerella cingulata spot) (Figure 2D).

The CDA shows that the fruit of the six 'Gala' strain do not differ, except for the area of red skin coloration. Improved area and intensity of red skin coloration is associated to an increased number of cells with red pigments in the hypodermal tissue of apple fruit (DICKINSON; WHITE, 1986). Mutations that alter only skin appearance (e.g. color) of apple fruit are thought to happens in histogenic layer I and or II of the bud meristems, from which the epidermis and hypodermis of fruit skins originate (DOORENBOS, 1977; DICKINSON; WHITE, 1986).

Regulating mechanisms of red pigments accumulation on apple skin have been suggested. Based on these mechanisms, the distinguished area of red skin coloration among the six 'Gala' strains of this study is likely associated either to the expression of the transcription factor (TF) MYB1, located in chromosome 9, that starts the expression of the anthocyanin biosynthetic pathway genes in apples (TAKOS et al., 2006) or to the different levels of methylation of the promoter region of MYB TFs (MA et al., 2018; JIA et al., 2020). Nevertheless, the somatic mutations that generate these six 'Gala' strains likely did not affect the genes encoding for fruit size, physicochemical and physiological measures related to fruit maturation on the tree and fruit ripening after harvest, as well to the occurrence of physiological disorders and diseases.

The differences in skin color among these six 'Gala' strain were not associated to fruit maturation on the tree as demonstrated in previous studies for many other 'Gala' strains selected for enhanced red skin coloration (GREENE; AUTIO, 1993; RAPILLARD; DESSIMOZ, 2000; IGLESIAS et al., 2008; IGLESIAS; ECHEVERRÍA, 2009). However, fruit of some 'Gala' strain with improved red coloration has not a single trait alteration. 'Obrogala' strain produces smaller fruit than other seven 'Gala' strains (IGLESIAS; ECHEVERRÍA, 2009) while 'Grand Gala' produces larger fruits (MALLADI; HIRST, 2010) and 'Premier Star' produces fruit with high sugar content (BROWN and MALONEY, 2013). 'Burnett', an early maturing 'Gala' strain produces fruit with less sugar content (FINN; CLARK, 2012) while 'Harry Black Gala', a late maturing 'Gala' strain produces firmer fruit (BROWN; MALONEY, 2002).

The rates of fruit softening and loss of titratable acidity during storage plus shelf life were the same for all six 'Gala' strains since they were not different regarding these variables at harvest and after storage (Tables 1 and 3 ). The fruit of six 'Gala' strains were also equally affected by physiological disorders and diseases (Tables 2 and 3), except for superficial scald, only detected in 'Imperial Gala' and 'Royal Gala' (Table 3). 'Gala' is considered a scald-resistant cultivar (LURIE; WATKINS, 2012). The incidence of this disorder was low and erratic, and therefore, it had no power to discriminate the strains by CDA. The smaller area of red skin color may account for the incidence of this disorder in 'Imperial Gala' and 'Royal Gala'. Superficial scald symptoms are normally restricted to green areas of the skin (TSANTILI et al., 2007), and the antioxidant activity of phenolic compounds of red skin area may contribute to resistance against superficial scald (LURIE; WATKINS, 2012).

The new 'Gala' strains with greater red colored surface areas (such as 'Baigent' and 'Galaxy') can increase financial returns to the producers. 'Baigent' and 'Galaxy' strains produce more fruits at high standard grades based on red skin color (Table 1, Figure 1), which have a higher market price (CAREW; SMITH, 2004). The characteristic warm and humid summer in apple growing region in southern Brazil is not favorable to red color development on apple fruit (TELIAS et al., 2011) and increases the incidence of fungal decay. The delay of the harvest to improve grade standards for color, particularly to less colored 'Gala' strains in warm summer years, shortens the length of storage and or increases production losses 
by fungal decay, flesh browning and fruit cracking during storage (ARGENTA; MONDARDO, 1994; CAMELDI et al., 2016; ARGENTA et al., 2018). Hence, the fruit loss by decay, senescent cracking and flesh browning during storage and supply chain can be reduced in highly red colored 'Gala' strains than in deficient red colored 'Gala' strains, despite of both having the same genetic susceptibility to these disorders.

Most growers have picked 'Royal Gala' and 'Imperial Gala' selectively 3 to 4 times from each tree, based on skin color (red color coverage and loss of green background color) due to the uneven fruit maturation within the tree canopy. However, the red coloration (a quality trait) develops earlier over most fruit surface in the fruit of 'Baigent' and 'Galaxy' strains hiding the change in ground color from green to yellow (a maturity index). This encourages growers to harvest the fruit in 1 to 2 pickings to improve efficiency and to reduce costs. Thus, when these highly red colored fruit are harvested in one or two pickings, they may have a uniform appearance but a wider range of maturity indices (starch index and firmness) in the bin and in the packing box. The higher variation of fruit maturity in the bin may increase fruit losses caused by senescent disorders flesh browning and cracking, particularly after long-term storage.

In summary, the fruit of the six 'Gala' strains with different extent of red skin coloration had the same maturity indices, weight and russeting index at harvest, as well as storability (maintenance of firmness and acidity and susceptibly to physiological disorders and fungal decay). There are potential economic benefits to the growers to produce highly red colored strains such as 'Baigent' and 'Galaxy'.

\section{Acknowledgements}

The technical assistance of Cleiton A. de Souza for fruit sampling and assessment and José Machado, José Hawerroth, and William Andolfato for orchard practices; the management of orchard establishment and practices by Dr. Paulo R. de Oliveira, Dr. Gabriel B. Leite, Dr. Eduardo C. Nunes, Dr. João C. Fioravanço, Dr. Marcelo Couto, and Dr. José M. Katsurayama. Financial support of this research provided by FINEP (Financiadora de Estudos e Projetos) and FAPESC (Fundação de Amparo à Pesquisa e Inovação de Santa Catarina). The scholarships to Karyne S. Betinelli, Thyana L. Brancher, and Vinícius A. Bartnicki granted by FIEPE (Fundação Instituto de Apoio ao Ensino, Pesquisa e Extensão) and CAPES (Coordenação de Aperfeiçoamento de Pessoal de Nível Superior).

\section{References}

ARGENTA, L.C.; MONDARDO, M. Maturação na colheita e qualidade de maçãs 'Gala' após a armazenagem. Revista Brasileira de Fisiologia Vegetal, São Paulo, v.6, n.2, p.135-140, 1994.

ARGENTA, L.C.; BENDER, R.J.; KREUS, C.L.; MONDARDO, M. Padrões de maturação e índices de colheita de maçãs cvs. Gala, Golden Delicious e Fuji. Pesquisa Agropecuária Brasileira, Brasília, DF, v.30, n.10, p.1259-1266, 1995.

ARGENTA, L.C.; VIEIRA, M.J.; SOUZA, F.D.; PEREIRA, W.S.P.; EDAGI, F.K. Diagnóstico da qualidade de maçãs no mercado varejista Brasileiro. Revista Brasileira de Fruticultura, Jaboticabal, v.37, n.1, p.48-63, 2015.

ARGENTA, L.C.; SCOLARO, A.M.T.; DO AMARANTE, C.v.T.; VIEIRA, M.J. Preharvest treatment of 'Gala' apples with 1-MCP and AVG - II: Effects on fruit quality after storage. Acta Horticulturae, The Hague, v.1194, p.127-133, 2018.

ARGENTA, L.C.; DOAMARANTE, C. v.T.; BETINELLI, K. S.; BRANCHER, T. L.; NESI, C. N.; VIEIRA, M. J. Comparison of fruit attributes of 'Fuji'apple strains at harvest and after storage. Scientia Horticulturae, New York, v.272, p.109585, 2020.

BROWN, S.K.; MALONEY, K. E. Apple cultivars: a Geneva perspective. New York Fruit Quarterly, Rochester, v.10, n.2, p.21-27, 2002.

BROWN, S. K.; MALONEY, K.E. An update on apple cultivars, brands and club-marketing. New York Fruit Quarterly, Rochester, v.21, n.1, p.3, 2013.

CAMELDI, I.; NERI, F.; VENTRUCCI, D.; CEREDI, G.; MUZZI, E.; MARI, M. Influence of harvest date on bull's eye rot of 'Cripps Pink' apple and control chemical strategies. Plant Disease, St Paul, v.100, n.11, p.22872293, 2016.

CAREW, R. A hedonic analysis of apple prices and product quality characteristics in British Columbia. Canadian Journal of Agricultural Economics, Ottawa, v.48, n.3, p.241-257, 2000.

CAREW, R.; SMITH, E.G. The value of apple characteristics to wholesalers in western Canada: A hedonic approach. Canadian Journal of Plant Science, Ottawa, v.84, n.3, p.829-835, 2004. 
CRASSWELLER, R.M.; HOLLENDER, R.A. Consumer evaluations of 'Delicious' apple strains. Fruit Varieties Journal, University Park, v.43, n.4, p.139-142, 1989.

DE HOOGE, I.E.; OOSTINDJER, M.; ASCHEMANNWITZEL, J.; NORMANN, A.; LOOSE, S.M.; ALMLI, V.L. This apple is too ugly for me!: Consumer preferences for suboptimal food products in the supermarket and at home. Food Quality and Preference, Oxford, v.56, p.80-92, 2017.

DICKINSON, J.P.; WHITE, A.G. Red colour distribution in the skin of Gala apple and some of its sport. New Zeland Journal of Agricultural Research, Lincoln, v.29, p.695-698, 1986.

DOORENBOS, J. Spontaneous mutation as a source of clonal variation on deciduous fruits. Acta Horticulturae, The Hague, v.75, p.13-18, 1977.

EPAGRI. Sistema de produção para a cultura da macieira em Santa Catarina. Florianópolis, 2018. 136 p. (Sistema de Produção, 50).

FINN, C.E.; CLARK, J.R. Register of new fruit and nut cultivars list 46. HortScience, Alexandria, v.47, n.5, p.536, 2012.

GREENE, D.W.; AUTIO, W.R. Comparison of tree growth, fruit characteristics, and fruit quality of five 'Gala' apple strains. Fruit Varieties Journal, University Park, v.47, n.2, p.103-109, 1993.

HAMADZIRIPI, E.T.; THERON, K.I.; MULLER, M.; STEYN, W.J. Apple compositional and peel color differences resulting from canopy microclimate affect consumer preference for eating quality and appearance. HortScience, Alexandria, v.49, n.3, p.384-392, 2014.

HAMPSON, C.R.; KEMP, H. Characteristics of important commercial apple cultivars. In: FERREE, D.C.; WARRINGTON, I.J. (ed.). Apples: botany, production and uses. Wallingford: CABI Publishing, 2003. p.61-89.

IGLESIAS, I.; ECHEVERRÍA, G.; SORIA, Y. Differences in fruit colour development, anthocyanin content, fruit quality and consumer acceptability of eight 'Gala' apple strains. Scientia Horticulturae, New York, v.119, n.1, p.32-40, 2008.

IGLESIAS, I.; ECHEVERRÍA, G. Does strain affect fruit color development, anthocyanin content and fruit quality in 'Gala' apples? A comparative study over three seasons. Journal of the American Pomological Society, University Park, v.63, n.4, p.168-180, 2009.
IGLESIAS, I.; ECHEVERRÍA, G.; LOPEZ, M.L. Fruit color development, anthocyanin content, standard quality, volatile compound emissions and consumer acceptability of several 'Fuji' apple strains. Scientia Horticulturae, New York, v.137, p.138-147, 2012.

JAEGER, S.R.; ANTÚNEZ, L.; ARES, G.; SWANEYSTUEVE, M.; JIN, D.; HARKER, F.R. Quality perceptions regarding external appearance of apples: Insights from experts and consumers in four countries. Postharvest Biology and Technology, Amsterdam, v.146, p.99-107, 2018.

JIA, D.; LI, Z.; DANG, Q.; SHANG, L.; SHEN, J.; LENG, X.; WANG, Y.; YUAN, Y. Anthocyanin biosynthesis and methylation of the MdMYB10 promoter are associated with the red blushed-skin mutant in the red striped-skin "Changfu 2" apple. Journal of Agricultural and Food Chemistry, Easton, v.68, n.15, p.4292-4304, 2020.

KAPPEL, F.; DEVER, M.; BOUTHILLIER, M. Sensory evaluation of 'Gala' and 'Jonagold' strains. Fruit Varieties Journal, University Park, v.46, n.1, p.37-43, 1992.

LURIE, S.; WATKINS, C.B. Superficial scald, its etiology and control. Postharvest Biology and Technology, Amsterdam, v.65, p.44-60, 2012.

MA, C.; JING, C.; CHANG, B.; YAN, J.; LIANG, B.; LIU, L.; YANG, Y.; ZHAO, Z. The effect of promoter methylation on MdMYB1 expression determines the level of anthocyanin accumulation in skins of two non-red apple cultivars. BMC Plant Biology, London, v.18, n.1, 2018.

MALLADI, A.; HIRST, P.M. Increase in fruit size of a spontaneous mutant of 'Gala' apple (Malus $\times$ domestica Borkh.) is facilitated by altered cell production and enhanced cell size. Journal of Experimental Botany, Oxford, v.61, n.11, p.3003-3013, 2010.

MAPA. Regulamento técnico de identidade e qualidade da maçã. Instrução Normativa, 5. Brasília, 2006. Avaliable at: http://sistemasweb.agricultura.gov.br/ sislegis/action/detalhaAto.do?method=visualizarAtoPo rtalMapa\&chave=805793610. Acessed on: June, 2019.

MENDIBURU, F. Agricolae: statistical procedures for agricultural research. $\mathrm{R}$ package version 1.2-8. Vienna: R Foundation for Statistical Computing, 2017.

OECD. International standards for fruit and vegetables. Apples. Paris, 2010. p.132. Disponível em: https://www.oecd-ilibrary.org/agriculture-and-food/ apples 9789264088795-en-fr. Acesso em: 01 jun. 2019. 
PÉRÈS, P.N. O mercado mundial e nacional de maçãs. In: ENCONTRONACIONAL SOBRE FRUTICULTURA DE CLIMA TEMPERADO, 11., 2009, Fraiburgo. Anais [...]. Caçador: EPAGRI, 2009. p.117-126.

RAPILLARD, C.; DESSIMOZ, A. Different mutants of Gala. Revue Suisse de Viticulture, d'Arboriculture et d'Horticulture, Lausanne, v.32, n.4, p.233-237, 2000.

TAKOS, A.M.; JAFFÉ, F.W.; JACOB, S.R.; BOGS, J.; ROBINSON, S.P.; WALKER, A.R. Light-induced expression of a MYB gene regulates anthocyanin biosynthesis in red apples. Plant Physiology, Rockville, v.142, n.3, p.1216-1232, 2006.

TEAM-R-CORE. R: a language and environment for statistical computing. Vienna: R Foundation for Statistical Computing, 2017. Disponível em: www.R-project.org.
TELIAS, A.; BRADEEN, J.M.; LUBY, J.J.; HOOVER, E.E.; ALLEN, A.C. Regulation of anthocyanin accumulation in apple peel. Horticultural Reviews, New York, v.38, p.357-391, 2011.

THOMAS, D. R.; ZUMBO, B. D. Using a measure of variable importance to investigate the standardization of discriminant coefficients. Journal of Educational and Behavioral Statistics, Washington, v.21, n.2, p.110-130, 1996.

TSANTILI, E.; GAPPER, N.E.; APOLLO ARQUIZA, J. M. R.; WHITAKER, B. D.; WATKINS, C. B. Ethylene and $\alpha$-farnesene metabolism in green and red skin of three apple cultivars in response to 1-methylcyclopropene (1-MCP) treatment. Journal of Agricultural and Food Chemistry, Easton, v.55, n.13, p.5267-5276, 2007.

WALSH, C. S.; VOLZ, R. 'Gala', and the red 'Gala' sports: a preliminary comparison of fruit maturity. Fruit Varieties Journal, University Park, v.44, n.1, p.18-23, 1990.

YUE, C.; JENSEN, H.H.; MUELLER, D.S.; NONNECKE, G. R.; BONNET, D.; GLEASON, M. L. Estimating consumers' valuation of organic and cosmetically damaged apples. HortScience, Alexandria, v.42, n.6, p.1366-1371, 2007. 